\title{
Foreign Terrorist Fighters and International Law
}

Veronika Bílková*

DOI: $10.21827 / 5 b 51 \mathrm{~d} 51 \mathrm{a} 22 \mathrm{ac} 3$

\author{
Keywords \\ FOREIGN TERRORIST FIGHTERS; HUMAN RIGHTS; INTERNATIONAL LAW; \\ TERRORISM; UN SECURITY COUNCIL
}

\begin{abstract}
The phenomenon of foreign fighting is not new. What is however unprecedented about it today is, in addition to its scale, the fact that it is more and more often conceptualized through the prism of the fight against terrorism. Attention has been turned from the situation at the battlefield to that in the countries of origin. The regulation no longer falls under the laws of armed conflict but under international criminal law or, even, under an emerging international counter-terrorism law. And foreign fighters have become foreign terrorist fighters. These developments may seem relatively insignificant; however, they represent a paradigmatic shift. And this shift comes with a price. The concept of foreign terrorist fighters and the international legal regulation applicable to it, stemming primarily from the UN Security Council Resolutions 2178 (2014) and 2396 (2017), give rise to legal challenges. The paper discusses three such challenges pertaining to the definition of foreign terrorist fighters, the construction of foreign terrorist fighters-related offences and the impact on human rights. The main message that the paper seeks to impart is to caution against an excessive 'terror-isation' of international life which, even if motivated by laudable purposes, has problematic consequences, thus constituting of itself a threat to the values that it is supposed to protect.
\end{abstract}

\section{Introduction}

Foreign fighting is not a new phenomenon. ${ }^{1}$ Crusaders in the Middle Ages and members of the International Brigades during the Spanish Civil War are but two examples of large groups of individuals leaving their country of origin to take an active part in an armed conflict abroad. Attempts to use legal instruments, including those of international law, to outlaw or regulate foreign fighting, or some forms thereof, are not new either. Treaty provisions and specialised treaties directed against mercenarism, introduced in the second half of the $20^{\text {th }}$ century, provide an example. What is however new and unprecedented about foreign fighting today is firstly, the scale of the phenomenon, and secondly, the fact that the phenomenon is more and more often conceptualised through the prism of the fight against terrorism. As to the scale, it is estimated that as much as 30.000 individuals originating from over 100 countries have over the past years gone to

Institute of International Relations, Prague, Faculty of Law, Charles University, bilkova@iir.cz. This paper was supported by the Fulbright-Masaryk Grant (2017-2018).

1 See Galperin Donnelly, M, Sanderson, TM, Fellman, Z, REPORT: Foreign Fighters in History, Washington, 1 April 2017, at <csis-prod.s3.amazonaws.com/s3fs-public/publication/171220_history_ foreign_fighter_project.pdf?0BW8DQ8MqR5e30PtnhLdqmke8NhDQcCt> (accessed 22 April 2018); Flores, M, "Foreign Fighters Involvement in National and International Wars: A Historical Survey" in De Guttry, A, Capone, F, Paulussen, C, eds, Foreign Fighters under International Law and Beyond (Asser/Springer, 2016) 27. 
join ISIS and its associated groups alone. ${ }^{2}$ Thousands of other individuals have left their country to take part in armed conflicts or internal disturbances in other parts of the world (Eastern Ukraine, Afghanistan, Nigeria, etc.).

The conceptualisation of the phenomenon has undergone changes as well. Attention has been turned from the situation at the battlefield to that in the countries of origin. The regulation no longer falls under the law of armed conflict but under international criminal law or, even, under an emerging international counter-terrorism law. And foreign fighters have become foreign terrorist fighters. These developments may seem relatively unimportant and mostly technical in nature. Yet, in reality, they represent a paradigmatic shift. And this shift comes at a price. The concept of foreign terrorist fighters, which is introduced in the first section of this paper, and the international legal regulation applicable to it, the object of the second section, give rise to legal challenges. The third section discusses three such challenges pertaining to the definition of foreign terrorist fighters, the construction of foreign terrorist fighters-related offences and the impact on human rights. The main message that the paper seeks to impart is to caution against an excessive 'terror-isation' of international life which, even if motivated by laudable purposes, may have problematic consequences, thus constituting of itself a threat to the values that it is supposed to protect.

\section{From Foreign Fighters to Foreign Terrorist Fighters}

The concept of foreign terrorist fighters emerged from that of foreign fighters in the mid2010s. While the two concepts may appear virtually identical at first sight, there are important differences between them. These differences relate both to the content of the concepts and to their legal status. Foreign fighter is not a legal term of art. It is absent from treaties and other instruments of international law, including those regulating armed conflicts such as the 1949 Geneva Conventions and the 1977 Additional Protocols. Despite that, the term has been regularly invoked in scholarly literature. ${ }^{3}$ In its broadest meaning, it denotes all persons who participate in an armed conflict taking place outside their country of origin and who do so while not serving in the armed forces of this country - either because the country is not involved in the relevant armed conflict or because they join armed forces of a different entity. Thus, foreign fighters are foreign, since they operate outside their country of origin (nationality or residence), and they are fighters, because they join armed forces taking part in an armed conflict.

Scholars usually embrace a more restrictive definition. For David Malet, foreign fighters are 'noncitizens of conflict states who join insurgencies during civil conflicts'. Building on this definition, Thomas Hegghammer identifies four defining features of foreign fighters. They are persons who: 1) have joined, and operate within the confines of an insurgency, 2) lack citizenship of the conflict state or kinship links to its warring factions, 3) lack affiliation to an official military organization, and 4) are unpaid. ${ }^{5}$ In a conference paper co-authored by Jeff Cogan, Hegghammer partly modifies this approach, concluding that ' $[t]$ he distinguishing features of foreign fighters are that (a) they are not

2 Schmid, AP, "Foreign (Terrorist) Fighter Estimates: Conceptual and Data Issues," The International Centre for Counter-Terrorism - The Hague 6, no. 4 (2015) 1.

3 See, for instance, Malet, D, Foreign Fighters: Transnational Identity in Civic Conflicts (Oxford University Press, 2013); Li, DA, "Universal Enemy? 'Foreign Fighters' and Legal Regimes of Exclusion and Exemption Under the 'Global War on Terror', " 41(2) Columbia Human Rights Law Review (2010) 355.

4 Malet, D, supra nt 3, 9.

5 Hegghammer, T, "The Rise of Muslim Foreign Fighters: Islam and the Globalization of Jihad," 35(3) Quarterly Journal: International Security (2010/2011) 53. 
overtly state sponsored; (b) they operate in countries which are not their own; (c) they use insurgent tactics to achieve their ends; and (e) their principal motivation is ideological rather than material reward'. ${ }^{6}$ On her turn, Sandra Kraehenmann defines a foreign fighter as 'an individual who leaves his or her country of origin or habitual residence to join a non-state armed group in an armed conflict abroad and who is primarily motivated by ideology, religion, and/or kinship'.

These definitions concur with the broader understanding of foreign fighters in that foreign fighters have to be foreigners and have to join a party to an armed conflict. Yet, they add certain other elements that narrow the concept down. The first element pertains to the affiliation. For Malet, Hegghammer and Cogan, and Kraehenmann, foreign fighters have to fight in the armed forces of a non-state armed group. Individuals who join the armed forces of a foreign state would thus be excluded from the definition. This may create difficulties in case of entities which exercise a longer-term control over a certain portion of territory but are not generally recognized as states, such as ISIS or separatist entities in Eastern Ukraine, as their status would not be completely clear. The same applies in armed conflicts where it is not fully clear which side represents the legitimate government and/or which armed groups act independently and which are, on the contrary, directly controlled by a state. Thus, the affiliation element, though often adhered to, has not secured general consensus and some scholars prefer to do away with it. $^{8}$

The second element relates to the motivation of foreign fighters. They should be unpaid or, at least, their primary motivation should not be material profit. That makes them different from mercenaries, who are 'motivated to take part in the hostilities essentially by the desire for private gain'. ${ }^{9}$ The perceived need to draw a line between those who fight for money and those who fight for other, immaterial reasons, stems from the conviction that the two groups pose different challenges. As Simon Chesterman notes, 'mercenaries are seen as threats in the states to which they travel, while foreign fighters are primarily deemed threats by the states to which they might return' ${ }^{10}$ In this perspective, mercenaries are relatively rational actors who simply go where the money is and for whom fighting is just a way to make a living. Foreign fighters, on the contrary, are fanatics who fight for their, mostly perverted, ideals and who may want to import these ideals, and the fight, back to their country of origin. In reality, however, the distinction is often not that clear-cut. People join armed groups for various motives. These motives, moreover, might be difficult to decipher, since foreign fighters are not always willing to unveil them. Some of them may not even be fully aware of these motives themselves. For this reason, the motivation element is, again, not generally accepted. ${ }^{11}$

6 Colgan, J, Hegghammer, T, "Islamic Foreign Fighters: Concept and Data," Paper presented at the International Studies Association Annual Convention, Montreal (2011) 6.

7 Kraehenmann, S, "Academy Briefing No. 7: Foreign Fighters under International Law" Geneva Academy of International Humanitarian Law and Human Rights (2010) 61.

8 See De Guttry, A, Capone, F, Paulussen, C, "Introduction" in De Guttry, A, Capone, F and Paulussen, C, eds, Foreign Fighters under International Law and Beyond (Asser/Springer, 2016), 2.

9 Article 47, International Committee of the Red Cross, Protocol Additional to the Geneva Conventions of 12 August 1949, and relating to the Protection of Victims of International Armed Conflicts (Protocol I) (1977) 1125 UNTS 3.

10 Chesterman, S, "Dogs of War or Jackals of Terror? Foreign Fighters and Mercenaries in International Law" 18(5) International Community Law Review (2016) 390, 389.

11 For instance, in his 2014 Report on the protection of human rights and fundamental freedoms while countering terrorism, the UN High Commissioner for Human Rights notes that although the primary 
Some scholars further narrow down the definition of foreign fighters by excluding from it those who fight due to their kinship with one of the armed factions. Despite the link to the motivation element, this exclusion seems to have more to do with the fact that fighting kins are not considered as truly foreign to the conflict. They have, as Hegghammer puts it, 'a preexisting stake in the conflict'. ${ }^{12}$ Kinship however can be based on various criterions (ethnicity, religion, ideology, etc.) and most foreign fighters would probably meet at least one of them. It is therefore more common to determine the 'foreignness' of foreign fighters merely in light of their formal legal status, i.e. their citizenship or habitual residence. Fighting due to the links of kinship is then put at pair with fighting for any other immaterial reasons such as ideology, religion, or personal search for identity.

As noted above, the term foreign fighter is not a legal term of art. Foreign fighters do not have any special status under international law. Nor are there any legal consequences automatically resulting from becoming a foreign fighter. The situation may be different under domestic law. Some national legal orders know a special offence of serving in foreign armed forces. This offence, however, is often qualified. In the United States, for instance, enlistment with the intent to serve in armed hostility is an offence only when the enlistment occurs 'within the US or in any other place subject to the jurisdiction thereof' and the person intends to engage in hostilities against the US. ${ }^{13}$ In the Czech Republic, the offence of serving in foreign military forces is only applicable to Czech citizens who serve in the military or armed forces of another State, not to those serving in the armed forces of a non-state actor. ${ }^{14}$ In yet other countries, it is not the enlistment as such but, rather, the recruitment for the service in a foreign military organization which is criminalized. ${ }^{15}$ In all these cases, the regulation is strictly domestic and there is no similar regulation at the international level.

In the mid-2010s, the concept of foreign fighters was complemented by that of foreign terrorist fighters. The latter is meant to be a legal term of art and to entail legal consequences. The concept was introduced in the UN Security Council Resolutions $2170^{16}$ and $2178,{ }^{17}$ which were adopted unanimously on 15 August and 24 September 2014 respectively, under Chapter VII of the UN Charter. The two resolutions aim at preventing the movement of individuals from the country of origin to the areas dominated by ISIS and similar entities. Such individuals are labelled as foreign terrorist fighters or, sometimes, simply terrorists. Resolution 2178, which was tabled by the US and sponsored by a large group of more than 120 states from all continents, is particularly important, because it provides a definition of foreign terrorist fighters both in its preamble and in its text. Under this definition, foreign terrorist fighters are 'individuals who travel or attempt to travel /.../ to a State other than their States of residence or nationality for the purpose of the perpetration, planning, or preparation of, or participation in, terrorist

motivation of foreign fighters is ideology or religion, they 'may also be motivated by payment'. UNGA Human Rights Council, Report of the United Nations High Commissioner for Human Rights on the protection of human rights and fundamental freedoms while countering terrorism, 19 December 2014, A/HRC/28/28, 1.

12 Hegghammer, supra nt 5.

$13 \S 2390$ of 18 US Code.

$14 \$ 321$ of the Criminal Code of the Czech Republic.

$15 \$ 109 \mathrm{~h}$ of the Criminal Code of Germany.

16 UNSC, Threats to international peace and security caused by terrorist acts, 15 August 2014, S/RES/2170 (2014).

17 UNSC, Threats to international peace and security caused by terrorist acts, 24 September 2014, S/RES/2178 (2014). 
acts or the providing or receiving of terrorist training'. ${ }^{18}$ This definition serves as the basis for the whole regime against foreign terrorist fighters and is taken over by most other instruments.

Although foreign terrorist fighters may at first sight appear to be almost identical to foreign fighters, the only element that the two concepts truly share is the foreignness in both cases, they are individuals who operate outside their country of origin. One could expect that another shared element would be that of fighting, i.e. taking part in an armed conflict. Yet, this is not the case. For an individual to qualify as a foreign terrorist fighter, participation in and, in fact, the existence of an armed conflict are not required. This is made clear by the definition in the preamble to Resolution 2178 which reads as quoted above but adds 'including in connection with armed conflict'. The presence of an armed conflict is thus possible but not necessary. Foreign terrorist fighters, who should better be labelled as foreign terrorists tout court, do not have to fight. They have to perpetrate, plan, prepare or participate in terrorist acts or provide or receive terrorist training. More exactly, it suffices if they travel, or attempt to travel, for the purpose of engaging in one of these activities. For foreign terrorist fighters, the element of fighting is replaced by that of engaging in terrorist activities. And the status is acquired already in the preparatory phase, prior to any such engagement and regardless of whether the individual in the end commits, or attempts to commit, any terrorist act.

Moreover, the definition of foreign terrorist fighters does not contain the additional elements linked to the affiliation and motivation. Although most foreign terrorist fighters associate themselves with non-state entities such as ISIS (rightly labelled as the 'Un-Islamic Non-State' by the former UN Secretary General Ban Ki-Moon ${ }^{19}$ ), this does not necessarily have to be so. Terrorist acts can be committed not only on behalf, or with the support, of a non-state entity but also on behalf, or with the support, of a state. Thus, although the affiliation element may be de facto present in the vast majority of cases, it is not required de jure. The situation is similar with respect to the motivation element. This element is absent from the definition, which applies to individuals regardless of whether they travel to engage in terrorist acts out of material or immaterial considerations. At the same time, it is often assumed that foreign terrorist fighters are led, or rather misled, by extremist ideologies, stressing that this is what makes them different from mercenaries, members of private military companies, or volunteers. ${ }^{20}$ Thus, the motivation element, although not required legally, is also often present in practice.

The concept of foreign terrorist fighters, while at first sight almost identical to that of foreign fighters, is therefore quite different from it. It is different in its content. Whereas foreign fighters are individuals who engage in an armed conflict outside their country of origin, supporting a non-state party to this conflict and acting out of immaterial reasons, foreign terrorist fighters are individuals who travel, or attempt to travel outside their country of origin, with the purpose of engaging in terrorism. The two concepts also differ in their status and aspirations. Whereas that of foreign fighters serves as a merely descriptive category, that of foreign terrorist fighters has prescriptive ambitions - it is meant to be a legal term of art and to entail legal consequences. What these consequences are will be discussed in the next section.

18 UNSC, supra nt 17 para 8 of the preamble and paras 5 and $6(a)$.

19 UNSC, Threats to international peace and security caused by terrorist acts, 24 September 2014, S/PV.7272, 3.

20 UN Office on Drugs and Crime, Foreign Terrorist Fighters. Manual for Judicial Training Institutes SouthEastern Europe (2017) 3. 


\section{Legal Regime Applicable to Foreign Terrorist Fighters}

The legal regime applicable to foreign terrorist fighters stems primarily from Resolution 2178 and several other resolutions adopted by the UN Security Council. This by itself is rather unusual. The Security Council was not created to legislate. Yet, this is exactly what it does in Resolution 2178. It is true that in some of its parts, the Resolution merely 'recalls' existing obligations or 'encourages' states to act in a certain way, thus 'not creating new obligations but merely suggesting States behave in a given manner'. ${ }^{21}$ In other parts, however, for instance when introducing the concept of foreign terrorist fighters, coining its definition and imposing upon states the obligation to criminalize certain acts related to this phenomenon, the Security Council 'decides' under Chapter VII of the UN Charter, thus establishing general legal rules which clearly apply beyond the current situation in the Middle East.

It is not the first time when the UN Security Council does not limit its attention to a concrete case, but adopts a general approach, focusing on a certain phenomenon rather than some manifestation thereof. Over the past two decades, it has done so repeatedly, mostly with respect to terrorism (Resolution 1373 of 2001, Resolution 1540 of 2004, etc.). ${ }^{22}$ Resolution 2178 , however, as Martin Scheinin rightly notes, goes one step further, as 'it imposes new legislative obligations upon Member States, without the existence of preceding treaty adopted by the General Assembly, and there is no way states could regularize the legal basis for their action by ratifying a treaty'. ${ }^{23}$ The large number of states which sponsored Resolution 2178, the unanimity in the adoption of this resolution and the absence of any substantive opposition to it seem nonetheless to suggest that in this case, the Security Council might have been successful in following the recommendation formulated by Stephan Talmon and 'to legislate only to an extent that reflects the general will of the member states' ${ }^{24}$ While this does not make the legislative efforts of the Council legally uncontroversial, it at least indicates that these efforts are not clearly unlawful.

Resolution 2178 follows on Resolution 2170, which was the first to use the term 'foreign terrorist fighters'. Resolution 2170 focuses specifically on the situation in the Middle East, in territories controlled by ISIS, Al-Nusrah Front and affiliated entities. It refers to foreign terrorist fighters in several places, but it does not concentrate on these fighters only, dealing with other issues such as terrorism financing as well. Having expressed its regret 'at the flow of foreign terrorist fighters' to the region and at 'the scale of this phenomenon', ${ }^{25}$ the Security Council demands that 'all foreign terrorist fighters

21 De Guttry, A, "The Role Played by the UN in Countering the Phenomenon of Foreign Terrorist Fighters" in De Guttry, A, Capone, F and Paulussen, C, eds, Foreign Fighters under International Law and Beyond (Asser/Springer, 2016), 275.

22 See Hinojosa Martinez, LM, "The Legislative Role of the Security Council in its Fight against Terrorism: Legal, Political and Practical Limits," 57 International and Comparative Law Quarterly (2008) 333.

23 Scheinin, M, A Comment on Security Council Resolution 2178 (Foreign Terrorist Fighters) as a "Form" of Global Governance, 6 October 2014, at <justsecurity.org/15989/comment-security-council-res-2178-foreignfighters-form-global-governance/> (accessed 23 May 2018). See also Scheinin, M, Back to post-9/11 panic? Security Council resolution on foreign terrorist fighters, 23 September 2014, at $<$ justsecurity.org/15407/post-911-panic-security-council-resolution-foreign-terrorist-fighters-scheinin/> (accessed 22 April 2018).

24 Talmon, S, "The Security Council as World Legislator," 99 American Journal of International Law (2005) $193,184$.

25 UNSC, supra nt 16 para 12 of the preamble. 
associated with ISIL and other terrorist groups withdraw immediately' ${ }^{26}$ The Council declares itself ready to consider listing anyone participating in the activities of such terrorist groups on the Al-Qaeda sanction list. It further calls upon states to take national measures to repress the flow of foreign terrorist fighters to the Middle East and to bring those fighters to justice. It also encourages states to 'engage with those within their territories at risk of recruitment and violent radicalisation to discourage travel to Syria and Iraq for the purposes of supporting or fighting for ISIL, ANF and all other individuals, groups, undertakings and entities associated with Al-Qaida' ${ }^{27}$

Resolution 2178, although also making repeated references to the situation in the Middle East and to the ISIS, is drafted in more general terms. As Andrea de Guttry notes, '[t]he scope of the Resolution is [...] universal and its application is not restricted to a given area or to a given armed conflict'. ${ }^{28}$ Moreover, Resolution 2178 concentrates specifically, and virtually exclusively, on foreign terrorist fighters. The Security Council first condemns 'the violent extremism, which can be conducive to terrorism, sectarian violence, and the commission of terrorist acts by foreign terrorist fighters' and demands that 'all foreign terrorist fighters disarm and cease all terrorist acts and participation in armed conflict'. ${ }^{29}$ It then recalls that states have the obligation to bring to justice those participating in the financing, planning, preparation or perpetration of terrorist acts. It further asks states to 'prevent and suppress the recruiting, organizing, transporting or equipping' of foreign terrorist fighters, and 'financing of their travel and of their activities'. ${ }^{30}$

To achieve this aim, states shall establish as criminal offences, subject to prosecution and penalisation in a manner duly reflecting their seriousness, three acts. The first is that of being a foreign terrorist fighter, i.e. to 'travel or attempt to travel to a State other than the States of residence or nationality for the purpose of the perpetration, planning, or preparation of, or participation in, terrorist acts, or the providing or receiving of terrorist training'. The other two consist of the financing of the travel of foreign terrorist fighters ${ }^{31}$ and of the wilful organization, or other facilitation, including acts of recruitment, of this travel. ${ }^{32}$ Furthermore, the resolution underscores the importance of countering violent extremism, which can be conducive to terrorism and to the mobilisation of foreign terrorist fighters, and encourages states to develop strategies in this respect and to engage local communities and civil society when doing so. Finally, the resolution incites states to improve international and regional cooperation to prevent the travel of foreign terrorist fighters and to share information and best practices related to this phenomenon. It also confirms the readiness of the UN Security Council to include foreign terrorist fighters - here only those travelling to the Middle East - to the Al-Qaeda

\footnotetext{
UNSC, supra nt 16 para 7.

UNSC, supra nt 16 para 9.

De Guttry, supra nt 21273.

UNSC, supra nt 17 para 1.

UNSC, supra nt 17 para 5.

31 UNSC, supra nt 17 para 6(b): "The wilful provision or collection, by any means, directly or indirectly, of funds by their nationals or in their territories with the intention that the funds should be used, or in the knowledge that they are to be used, in order to finance the travel of individuals who travel to a State other than their States of residence or nationality for the purpose of the perpetration, planning, or preparation of, or participation in, terrorist acts or the providing or receiving of terrorist training."

32 UNSC, supra nt 17 para 6(c): "The wilful organization, or other facilitation, including acts of recruitment, by their nationals or in their territories, of the travel of individuals who travel to a State other than their States of residence or nationality for the purpose of the perpetration, planning, or preparation of, or participation in, terrorist acts or the providing or receiving of terrorist training."
} 
sanction list, and requests several international organs (Interpol, UN Counter-Terrorism Committee, etc.) to help states in countering the phenomenon of foreign terrorist fighters.

Resolution 2178 has been supplemented by subsequent resolutions and by other international instruments. Since 2014, the UN Security Council has adopted more than ten resolutions referring to foreign terrorist fighters. Most of them do so in a rather cursory way, mentioning the concept only it their preamble. ${ }^{33}$ Some, however, go more to depth, restating existing obligations or introducing new ones. ${ }^{34}$ Particularly interesting are Resolutions $2368^{35}$ and $2396,{ }^{36}$ adopted on 20 July and 21 December 2017 respectively. These two resolutions extend the focus from individuals leaving the country of origin to join terrorist organizations abroad to those returning from abroad. The resolutions reflect the factual development in the Middle East, where individuals were first heading in the first half of the 2010s and from where they have started to return after the defeat of ISIS in 2017-2018. However, similarly as Resolution 2178, Resolutions 2368 and, especially, 2396 introduce general rules, which are not territorially limited to the Middle East.

Resolution 2368, which is certainly one of the longest resolutions ever adopted, expresses concerns over 'foreign terrorist fighters leaving zones of armed conflict, returning to their countries of origin, transiting through, travelling to or relocating to or from other Member States' ${ }^{37}$ It calls upon states to address this phenomenon and to cooperate and share information and best practices when doing so. Resolution 2396 is, to a large extent, a counterpart to Resolution 2178 . Tabled by the US, sponsored by a group of some 70 states from several continents and voted unanimously, it establishes a legal regime applicable to foreign terrorist fighters returning to their countries of origin or relocating to third states (returnees and relocators ${ }^{38}$ ). The resolution does not contain a definition of returnees and relocators though. Such a definition is considered unnecessary, because the instrument simply applies to foreign terrorist fighters, defined in Resolution 2178, who return to their countries of origin or travel to relocate to a third country. Rather than pertaining to two different phenomena, Resolutions 2178 and 2396 thus deal with two different sides of the same coin, the former focusing on individuals leaving their country of origin to engage in terrorism (foreign terrorist fighters), the latter on individuals returning to those countries after such an engagement (returnees and relocators).

33 See UNSC, Threats to international peace and security, 19 December 2014, S/RES/2195 (2014), para 19 of the preamble and para 22; UNSC, Threats to international peace and security caused by terrorist acts, 20 November 2015, S/RES/2249 (2015), para 5 of the preamble; UNSC, Middle East (Syria), 22 December 2015, S/RES/2258 (2015), para 7 of the preamble; UNSC, The situation in the Middle East (Syria), 17 November 2016, S/RES/2319 (2016), paras 5 and 7 of the preamble; UNSC, Threats to international peace and security caused by terrorist acts, 24 May 2017, S/RES/2354 (2017), para 14 of the preamble; UNSC, Threats to international peace and security, 21 September 2017, S/RES/2379 (2017), para 3 of the preamble; UNSC, The situation in the Middle East, 19 December 2017, S/RES/2393 (2017), para 7 of the preamble; UNSC, Threats to international peace and security caused by terrorist acts, 21 December 2017, S/RES/2395 (2017), paras 12 and 24 of the preamble.

34 See UNSC, Threats to international peace and security caused by terrorist acts: Aviation security, 22 September 2016, S/RES/2309 (2016), para 8; UNSC, Threats to international peace and security caused by terrorist acts, 12 December 2016, S/RES/2322 (2016), paras 3, 5, 16, 19 and 20.

35 UNSC, Threats to international peace and security caused by terrorist acts, 20 July 2017, S/RES/2368 (2017).

36 UNSC, Threats to international peace and security caused by terrorist acts, 21 December 2017, S/RES/2396 (2017).

37 UNSC, supra nt 35 para 38 of the preamble.

38 See US Mission to the United Nations, Fact Sheet: Resolution 2396 (2017) on Foreign Terrorist Fighters (Returnees and Relocators), 21 December 2017. 
Resolution 2396 calls upon states 'to assess and investigate suspected individuals whom they have reasonable grounds to believe are terrorists, including suspected foreign terrorist fighters' and 'to develop and implement comprehensive risk assessments for those individuals, and to take appropriate action, including by considering appropriate prosecution, rehabilitation, and reintegration measures'. ${ }^{39}$ Despite the call for prosecution, no new criminal offences are introduced. Resolution 2396 merely recalls the offences established by Resolution 2178. In her speech at the Security Council, the US representative identified four main measures introduced by Resolution $2396 .{ }^{40}$ The first relates to the detection and disruption of terrorist travel across borders. States are asked to develop and implement systems to collect biometric data, and to develop watchlists or databases of known and suspected terrorists, including foreign terrorist fighters. Secondly, the resolution 'recognizes the need to counter this threat /of terrorism/ in a tailored, nuanced way'. ${ }^{41}$ Thirdly, states have to cooperate and to share information and best practices. Fourthly, the resolution 'boosts the UN own work addressing the foreign terrorist fighter threat'. ${ }^{42}$

Instruments relating to foreign terrorist fighters have been adopted outside the UN framework as well, mostly to facilitate the implementation of Resolution $2178 .{ }^{43}$ This is the case of the Additional Protocol to the Convention on the Prevention of Terrorism, ${ }^{44}$ adopted within the Council of Europe on 22 October 2015 and entered into force on 1 July 2017. The Protocol supplements the Council of Europe Convention on the Prevention of Terrorism ${ }^{45}$ adopted on 16 May 2005. Although the term 'foreign terrorist fighters' is not used in the text, the preamble of the Protocol quotes the definition of foreign terrorist fighters present in Resolution 2178. The Explanatory Report explicitly confirms that 'the main objective of the Additional Protocol should be to supplement the [...] Convention with a series of provisions aimed at implementing the criminal law aspects of UNSCR 2178' ${ }^{46}$ When compared to Resolution 2178, the Protocol is less comprehensive. It focuses solely on the criminal law aspects of the foreign terrorist fighter phenomenon.

By virtue of Articles 2-6 of the Protocol, states are requested to criminalize five acts. Three are taken over from Resolution 2178 - travelling abroad for the purpose of terrorism, funding travelling abroad for the purpose of terrorism, and organising or

39 UNSC, supra nt 36 para 29.

40 UNSC, Threats to international peace and security caused by terrorist acts, 21 December 2017, S/RES/PV.8148, 3.

41 Ibid.

42 Ibid.

43 Global Counterterrorism Forum, REPORT: The Hague - Marrakech Memorandum on Good Practices for a More Effective Response to the FTF Phenomenon, 19 September 2014, at < thegctf.org/documents/10162/140201/ 14Sept19_The+Hague-Marrakech+FTF+Memorandum.pdf> (accessed 22 April 2018): There are also soft law instruments on foreign terrorist fighters. Particularly worth mentioning is The Hague - Marrakech Memorandum on Good Practices for a More Effective Response to the FTF Phenomenon, which was adopted on 23 September 2014, one day before the adoption of Resolution 2178, by the Global Counterterrorism Forum, an informal multilateral platform launch in 2011 and chaired by Morocco and the Netherlands. The Memorandum contains 19 instances of good practices, which "are intended to inform and guide governments as they develop policies, programs, and approaches to address the FTF phenomenon" (1).

44 Additional Protocol to the Council of Europe Convention on the Prevention of Terrorism, CETS No.217. By 31 March 2018, the Additional Protocol has secured 12 ratifications and 29 signatures, including the signature by the European Union.

45 The Convention requests to criminalize public provocation to commit a terrorist act, recruitment for terrorism, and training for terrorism.

46 Council of Europe, Draft Explanatory Report to the Additional Protocol to the Council of Europe Convention on the Prevention of Terrorism (2015) CETS 217 para 5. 
otherwise facilitating travelling abroad for the purpose of terrorism. Two other acts, participating in an association or group for the purpose of terrorism and receiving training for terrorism, go beyond the scope of the resolution, though they are linked to the phenomenon of foreign fighters as well. Apart from an article on the exchange of information, the Protocol does not contain any provisions on the implementation. Here, the provisions of the Convention apply in a subsidiary way. ${ }^{47}$ The Convention regulates all the important issues relating to criminal prosecution, such as jurisdiction, extradition or the rights of victims. It enshrines the aut dedere, aut judicare principle and establishes the duty to investigate. The only provision of the Convention which is inapplicable under the Protocol is Article 9 dealing with ancillary offences. It is, so because acts to be criminalized under the Protocol are in themselves ancillary in nature. ${ }^{48}$

Within the European Union, Resolution 2178 has been implemented through the Directive 2017/541 of 15 March 2017 on Combating Terrorism. ${ }^{49}$ In its preamble, the Directive notes that "[i]ndividuals referred to as "foreign terrorist fighters" travel abroad for the purpose of terrorism. Returning foreign terrorist fighters pose a heightened security threat to all Member States' ${ }^{50}$ It then stresses that '[c]onsidering the seriousness of the threat $[\ldots]$, it is necessary to criminalise outbound travelling for the purpose of terrorism [...]', ${ }^{51}$ adding however, in a somewhat ambiguous way, that '[i]t is not indispensable to criminalise the act of travelling as such' ${ }^{52}$ The operative part of the Directive contains a list of offences that the EU members have to criminalize. Among them are travelling for the purpose of terrorism; organising or otherwise facilitating travelling for the purpose of terrorism; and financing of terrorism. ${ }^{53}$ The definitions of these offences, which are also provided, differ to some extent from those in Resolution 2178 and the Protocol. Most importantly, the first offence also includes travelling 'for the purpose of the participation in the activities of a terrorist group with knowledge of the fact that such participation will contribute to the criminal activities of such a group' ${ }^{54}$

\section{Legal Challenges Posed by Foreign Terrorist Fighters}

The concept of foreign terrorist fighters and the legal regime built around it give rise to several legal challenges. ${ }^{55}$ One, related to the legislative nature of Resolution 2178 , has already been mentioned. This challenge has to do with the division of powers among the UN organs, as well as between the UN and its Members States and with the principles of the rule of law as applicable at the international level. Moreover, it may also have an impact on human rights, especially were it to be found that Resolution 2178 or any other

47 See Article 9 of the Additional Protocol.

48 As the Explanatory Memorandum makes it clear, states remain free to introduce ancillary offences. If they do so, however, they should be cautious not to run into absurd, and legally controversial, situations, when people would be prosecuted for an attempt to attempt to travel to attempt to commit a terrorist act. COD-CTE (015) 3 final, Draft Explanatory Report to the Additional Protocol to the Council of Europe Convention on the Prevention of Terrorism, 26 March 2015, para 48.

49 Directive (EU) 2017/541 of the European Parliament and of the Council of 15 March 2017 on combating terrorism and replacing Council Framework Decision 2002/475/JHA and amending Council Decision 2005/671/JHA.

50 Directive (EU) 2017/541, supra nt 49 para 4.

51 Directive (EU) 2017/541, supra nt 49 para 12.

52 Directive (EU) 2017/541, supra nt 49 para 12.

53 Directive (EU) 2017/541, supra nt 49 Article 9-11.

54 Directive (EU) 2017/541, supra nt 49 Article 9(1).

55 See Capone, F, "Countering "Foreign Terrorist Fighters": A Critical Appraisal of the Framework Established by the UN Security Council Resolutions," 25 Italian Yearbook of International Law (2016) 227. 
resolution on foreign terrorist fighters impose direct obligations on individuals. That is what Anne Peters, analysing Resolution 2178, claims might be the case. She argues that the Security Council is in the position to legislative for individuals, because the UN Charter, which enjoys a special legal quality [...] endows the Security Council with a special authority that $[. .$.$] also is effective erga omnes vis-à-vis individuals' { }^{56}$ Although Peters concludes that this authority has not been deployed in resolution 2178, which 'is not itself the basis for criminalising the behaviour it seeks to suppress', ${ }^{57}$ the potential is there and where it to materialise, the principle of legality would apply.

While the UN Security Council resolutions on foreign terrorist fighters are not directly binding on individuals, there is no doubt that those adopted under Chapter VII are, in parts formulated as decisions, binding on states. In addition to the general question of legislative powers, there are more specific issues related to the content of Resolution 2178 and of other instruments on foreign terrorist fighters. These issues pertain, primarily, to the definition of foreign terrorist fighters, to the construction of foreign terrorist fighters-related offences to be criminalized at the national level, and to the potential impact of the regulation on human rights. These three issues are interlinked. For the purpose of this analysis, they will nonetheless be dealt with separately as much as this is possible. The list of challenges is not meant to be an exhaustive one, as there are certainly other issues at stake (e.g. the relationship with international humanitarian law).

\section{A. Definition of foreign terrorist fighters}

The definition of foreign terrorist fighters, to recall, is provided for in Resolution 2178. Under this Resolution, foreign terrorist fighters are 'individuals who travel or attempt to travel [...] to a State other than their States of residence or nationality for the purpose of the perpetration, planning, or preparation of, or participation in, terrorist acts or the providing or receiving of terrorist training, ${ }^{58}$ This definition is taken over by other instruments on foreign terrorist fighters, such as the Protocol, and is also used as the basis for defining other concepts, in particular that of returnees and relocators. The EU, as we established above, elaborates on the final part of the definition, adding 'the purpose of the participation in the activities of a terrorist group with knowledge of the fact that such participation will contribute to the criminal activities of such a group' ${ }^{59}$

At first sight, the definition may seem rather clear. Yet, as is often the case, the devil is in the detail, this time in the reference to terrorist acts. Nowhere in Resolution 2178 is this term defined. The European instruments score better in this respect. The Convention on the Prevention of Terrorism, which the Protocol supplements, defines terrorist acts by reference to 'any of the offences within the scope of and as defined in one of the treaties listed in the Appendix' (Article 1). The Appendix contains the list of 12 sectorial counter-terrorist treaties adopted at the universal level in 1970-2005. The EU Directive contains an updated EU definition of terrorism, which combines a long list of violent acts which, when committed with the aim of '(a) seriously intimidating a population, (b) unduly compelling a government or an international organisation to perform or abstain

56 EJIL: Talk!, Peters, A, Security Council Resolution 2178 (2014): The "Foreign Terrorist Fighter" as an International Legal Person, Part I, 20 November 2014, at <ejiltalk.org/security-council-resolution-21782014-the-foreign-terrorist-fighter-as-an-international-legal-person-part-i/> (accessed 23 May 2018).

57 EJIL: Talk!, Peters, A, Security Council Resolution 2178 (2014): The "Foreign Terrorist Fighter" as an International Legal Person, Part II, 21 November 2014, at <ejiltalk.org/security-council-resolution-21782014-the-foreign-terrorist-fighter-as-an-international-legal-person-part-ii/> (accessed 23 May 2018).

58 UNSC, supra nt 17 para. 8 of the preamble and paras 5 and $6(\mathrm{a})$.

59 Directive (EU) 2017/541, supra nt 49 Article 9(1). 
from performing any act; or (c) seriously destabilising or destroying the fundamental political, constitutional, economic or social structures of a country or an international organization', ${ }^{60}$ qualify as a terrorist offence. Yet, the Protocol and the Directive only apply in the regional framework and most states are thus solely bound by Resolution 2178.

Some authors commenting on this resolution claim that the absence of the definition of terrorism is not really a problem. De Guttry, for instance, considers that the definition of foreign terrorist fighters 'reflects, to some extent, already-existing definitions proposed by the scientific community'. ${ }^{61} \mathrm{He}$ then makes references to the definitions of terrorism proposed by certain scholars, for instance, Bruce Hoffman. ${ }^{62}$ Since, however, the definition of foreign terrorist fighters provided for in Resolution 2178 merely refers to terrorist acts without trying to define these acts or terrorism as such, it is unclear how it could reflect any (academic or other) definition of terrorism. Peters takes a more nuanced approach. She submits that '[a]rguably, an international common ground on the notion of "terrorism" has already emerged" ${ }^{63}$ finding its expression in the UN Security Council Resolution $1566,{ }^{64}$ adopted on 8 October 2004. In Peters' view, 'the reference, in res. 2178 , to "terrorism" and "terrorist acts", is sufficiently clear so as to prohibit terrorist acts'. ${ }^{65}$ Kai Ambos goes one step further, claiming that the definition of terrorism contained in Resolution 1566 'is, in essence, the definition of international terrorism recognised by customary international law, which also forms the basis for a UN draft treaty of 2010 and is referred to in international jurisprudence $/ . . . /{ }^{66}$

Resolution 1566 is invoked by other authors as well. Scheinin opines that '[w]hile SCR 1566 may not be a perfect definition of terrorism, it nevertheless is the best that the Security Council has said in the matter' ${ }^{67}$ Scheinin, however, does not seem to be fully convinced that this definition is customary in nature and that, as such, it applies automatically in the absence of an express reference to it. ${ }^{68} \mathrm{He}$ therefore laments that Resolution 2178

60 Directive (EU) 2017/541, supra nt 49 Article 3(2).

61 De Guttry, supra nt 21 270-271.

62 Hoffman, B, Inside Terrorism, (Revised and Expanded Edition, Columbia University Press 2006), 40.

63 Peters, supra nt 56.

64 UNSC, Threats to international peace and security caused by terrorist acts, 8 October 2004, S/RES/1566 (2004). Resolution 1566 defines terrorist acts as "criminal acts, including against civilians, committed with the intent to cause death or serious bodily injury, or taking of hostages, with the purpose to provoke a state of terror in the general public or in a group of persons or particular persons, intimidate a population or compel a government or an international organization to do or to abstain from doing any act, which constitute offences within the scope of and as defined in the international conventions and protocols relating to terrorism, are under no circumstances justifiable by considerations of a political, philosophical, ideological, racial, ethnic, religious or other similar nature" (para 3).

65 Peters, supra nt 56.

66 EJIL: Talk!, Ambos, K, Our terrorists, your terrorists? The United Nations Security Council urges states to combat "foreign terrorist fighters", but does not define "terrorism", 2 October 2014, at <ejiltalk.org/ourterrorists-your-terrorists-the-united-nations-security-council-urges-states-to-combat-foreign-terroristfighters-but-does-not-define-terrorism/> (accessed 23 May 2018).

67 Scheinin, Back to post-9/11 panic?, supra nt 23.

68 This reflects the position that Scheinin took in his 2005 report to the Commission on Human Rights that he drafted as the first Special Rapporteur on the promotion and protection of human rights and fundamental freedoms while countering terrorism, see UN Economic and Social Council, Scheinin, M, REPORT: Promotion and Protection of Human Rights. Report of the Special Rapporteur on the promotion and protection of human rights and fundamental freedoms while countering terrorism, Martin Scheinin, Doc E/CN.4/2006/98, 28 December 2005, at <undocs.org/en/E/CN.4/2006/98> (accessed 22 April 2018): 
imposes upon all Member States far-reaching new legal obligations without any effort to define or limit the categories of persons who may be identified as 'terrorists' by an individual state. This approach carries a huge risk of abuse, as various states apply notoriously wide, vague or abusive definitions of terrorism, often with a clear political or oppressive motivation. ${ }^{69}$

This view is shared by others. Bibi Van Ginkel notes that Resolution 2178 'certainly does not define what terrorism means. It once again leaves it to states to decide and identify who falls under this category. [...] It is a missed opportunity that the Security Council [...] did not refer to resolution 1566 in which it came up with a definition of terrorism $[\ldots]^{\prime 70}{ }^{70}$ Letta Tayler notes that Resolution 2178 'does not set limitations on what "terrorism" means. This omission allows governments to criminalize as "terrorist acts" an array of internationally protected activities' ${ }^{71}$ Even Ambos, despite his view that the definition of terrorism in Resolution 1566 is customary, opines that 'Resolution 2178 [...] ultimately leaves it up to each UN member state to apply the measures called for to those individuals defined as "terrorist" by that respective state itself". ${ }^{72}$

There is no doubt that with the increased attention paid to the fight against terrorism in the past decades, especially since 11 September 2001, common legal standards have started to emerge in this area. It is also true that over this period, several instruments have introduced definitions of terrorism and that those definitions largely overlap. ${ }^{73}$ The instruments encompass, in addition to Resolution 1566, the UN General Assembly Resolution 49/60 of 1994, ${ }^{74}$ the 1999 International Convention for the Suppression of the Financing of Terrorism ${ }^{75}$ and the Draft Comprehensive Convention on International Terrorism. ${ }^{76}$ In 2011, moreover, the Special Tribunal for Lebanon (STL), in its decision on

69 Scheinin, Back to post-9/11 panic?, supra nt 23.

70 International Centre for Counter-Terrorism, Van Ginkel, B, The New Security Council Resolution 2178 on Foreign Terrorist Fighters: A Missed Opportunity for a Holistic Approach, 4 November 2014, at $<$ icct.nl/publication/the-new-security-council-resolution-2178-on-foreign-terrorist-fighters-a-missedopportunity-for-a-holistic-approach/> (accessed 23 May 2018).

71 Tayler, L, "Foreign Terrorist Fighter" Laws. Human Rights Rollbacks Under UN Security Council Resolution 2178," 18(5) International Community Law Review (2016) 455.

72 Ambos, supra nt 66 .

73 See also Saul, B, Defining Terrorism in International Law, (Oxford University Press, Oxford, 2006).

74 UNGA, Measures to eliminate international terrorism, 9 December 1994, A/RES/49/60. In its par. I(3), the Resolution refers to "/c/riminal acts intended or calculated to provoke a state of terror in the general public, a group of persons or particular persons for political purposes".

75 UNGA, International Convention for the Suppression of the Financing of Terrorism, 9 December 1999. The Convention was adopted by the UN General Assembly Resolution 54/109 of 9 December 1999 and it entered into force on 10 April 2002. By 31 March 2018, it had 188 State parties. In its Article 2(1)(b), the Convention defines as terrorism, for the purposes of financing of terrorism, "[a]ny other act intended to cause death or serious bodily injury to a civilian, or to any other person not taking an active part in the hostilities in a situation of armed conflict, when the purpose of such act, by its nature or context, is to intimidate a population, or to compel a government or an international organization to do or to abstain from doing any act". Many of the provisions of this Convention have been made binding on all States by means of the UN Security Council Resolution 1373. The definition of terrorism contained in the Convention is, however, not mentioned in Resolution 1373.

76 Letter dated 96/11/01 from the Permanent Representative of India to the United Nations addressed to the Secretary-General, Draft Comprehensive Convention on International Terrorism, 11 November 1996, A/C.6/51/6. Draft Article 2 stipulates that "[a]ny person commits an offence within the meaning of the present Convention if that person, by any means, unlawfully and intentionally, causes: (a) Death or serious bodily injury to any person; or (b) Serious damage to public or private property, including a 
the applicable law, held that 'a customary rule of international law regarding the international crime of terrorism, at least in time of peace, has indeed emerged. This customary rule requires the following three key elements: (i) the perpetration of a criminal act (such as murder, kidnapping, hostage-taking, arson, and so on), or threatening such an act; (ii) the intent to spread fear among the population (which would generally entail the creation of public danger) or directly or indirectly coerce a national or international authority to take some action, or to refrain from taking it; (iii) when the act involves a transnational element'. ${ }^{77}$ It is the STL decision that Ambos invokes when speaking about the customary definition of terrorism referred to in international jurisprudence. $^{78}$

For a definition to emerge under customary law, there would need to be, as the STL recalls, a general opinio juris in the international community, accompanied by a practice consistent with such an opinio. The general opinio juris would need to relate both to the binding nature of the definition and to its constitutive elements. Yet, a closer look at the definitions present in international instruments reveals that these definitions are not completely identical. First, the definitions differ in their descriptions of both the actus reus (e.g. some limit terrorist acts to acts directed against civilians, others do not) and mens rea (e.g. some require specific motivation, others do not). Secondly, there are the well-known disagreements over the personal scope of application of the definition. Individuals acting on behalf of states, especially as members of their armed forces, and those acting on behalf of national liberation movements are the main groups that, in some views, should not be subject to the definition, because their acts are adequately covered by other norms of international law (especially norms of international humanitarian law).

Thirdly, the application of the definition in times of armed conflict remains uncertain. The STL recognizes this uncertainly when stating that 'while the customary rule $[. .$.$] so far only extends to terrorist acts in times of peace, a broader norm that would$ outlaw terrorist acts during times of armed conflict may also be emerging'. ${ }^{79}$ Whether this broader norm, encompassing a definition of terrorist acts committed in times of armed conflict, would be identical to the peace-time definition, is not clear but the provisions on terrorism in the instruments of international humanitarian law and the references to this law in counter-terrorist instruments suggest that it does not necessarily need to be so. ${ }^{80}$ Since foreign terrorist fighters typically operate in times of armed conflict, this element would merit closer consideration.

Fourthly, the definitions do not serve identical purposes. The STL focuses on terrorism as a crime under international law, alongside such crimes as genocide, crimes against humanity, war crimes and the crime of aggression. The resolutions and treaties, on their turn, seek to coordinate and harmonize inter-State cooperation in the prevention and suppression of terrorism as a transnational crime. Peters argues that Resolution 2178 could not serve as 'the basis for criminalising the behaviour it seeks to suppress', ${ }^{81}$ i.e.

place of public use, a State or government facility, a public transportation system, an infrastructure facility or to the environment; or (c) Damage to property, places, facilities or systems referred to in paragraph 1 (b) of the present article resulting or likely to result in major economic loss; when the purpose of the conduct, by its nature or context, is to intimidate a population, or to compel a Government or an international organization to do or to abstain from doing any act".

77 Special Tribunal for Lebanon, Interlocutory Decision On The Applicable Law: Terrorism, Conspiracy, Homicide, Perpetration, Cumulative Charging, TL-11-01/I/AC/R176 bis, 16 February 2011, para 85.

78 Ambos, supra nt 66.

79 Special Tribunal for Lebanon, supra nt 77 para 107.

80 See Bianchi, A, Naqvi, , Y, International Humanitarian Law and Terrorism (Hart, 2011).

81 Peters, supra nt 57. 
acts of foreign terrorist fighters, because it 'resembles the classic suppression conventions'. ${ }^{82}$ The same holds for the resolutions and treaties proposing a definition of terrorism. While it could be expected that the definitions of terrorism as a transnational crime and as an international crime should be similar, if not identical, with the latter emerging on the basis of the former by adding the individual criminal responsibility element, this cannot be taken for granted. Moreover, the STL claim that terrorism is an autonomous crime under international law has been contested exactly on the grounds that there is still no customary definition of terrorism even within international criminal law in the broad sense, as applicable to transnational crimes.

The survey of domestic legal orders reveals that the national practice in this area is not uniform either. ${ }^{83}$ In fact, scholars, non-governmental organizations and UN experts have repeatedly lamented the plurality of the definitions of terrorism that states, and sometimes different institutions within a state, use. ${ }^{84}$ It might certainly be possible to argue that an international definition of terrorism exists but some states deviate from it, either violating the common international standard or assuming the position of a persistent objector. Yet, the number of such states, together with the plurality and diversity of definitions at the international level, suggests that this common standard might simply not exist in the first place. In this situation, the fears expressed as to the potential divergence in the interpretation of the concept of foreign terrorist fighters, which builds on the concept of terrorism, are well warranted and it is to be regretted that the Security Council failed to incorporate a definition of terrorism, or refer to the definition present in Resolution 1566, in its instruments on foreign terrorism fighters.

\section{B. Construction of the foreign terrorist fighters-related offences}

Resolution 2178 and the subsequently adopted instruments seek to harmonize, and make work, criminal prosecution of foreign terrorist fighters. To achieve this aim, they impose on states the obligation to first criminalise and penalise certain foreign terrorist fightersrelated offences, and then to prosecute, or extradite for the purpose of prosecution, individuals suspected of having committed some of those offences. Resolution 2178 and the Protocol concentrate primarily on acts that have to do with the travel, and preparation for the travel, from the country of origin. The newer instruments, especially Resolution 2396, expand the focus to individuals returning to this country or relocating to a third state, though it could be argued that this element has been present in the regulation from the beginning ${ }^{85}$ and that it has merely become more prominent over the past couple of years due to the developments of the factual situation in the Middle East.

Although the two processes - leaving the country and returning to it - are closely interlinked, representing two stages in the life-cycle of a foreign terrorist fighter, the approach to their criminalisation differs. For the former situation (travel), the instruments introduce new criminal offences that states have to incorporate into their domestic legal orders. For the latter situation (return), they do not do so, merely calling upon states to prosecute returners and relocators based on already existing provisions of their legal

82 Peters, supra nt 57.

83 See Setty, S, "What's in a Name? How Nations Define Terrorism Ten Years after 9/11" 33(1) University of Pennsylvania Journal of International Law (2011) 1; Schmid, A, "Terrorism - The Definitional Problem" 36(2) Case Western Reserve Journal of International Law, (2004) 375.

84 See Webber, D, Preventive Detention of Terror Suspects: A New Legal Framework, (1 ${ }^{\text {st }}$ ed, Routledge, 2016) 6; Tayler, supra nt 71; Scheinin, supra nt 68 para 27.

85 Resolution 2178 also speaks about the need to "develop and implement prosecution, rehabilitation and reintegration strategies for returning foreign terrorist fighters". UNSC, supra nt 17 para 4. 
orders. The rationale for this differentiated approach is quite simple. Most states have traditionally had legal tools to prosecute those who engaged in armed conflicts or terrorist activities abroad. At the same time, they might not have tools to use against those who merely prepare or contemplate such an engagement, or these tools (ancillary offences in most cases) might not be specific or strong enough. That, coupled with the developments on the grounds, also explains why the international regulation first and foremost focuses on departing foreign terrorist fighters rather than on returnees and relocators.

In both cases, however, the regulation is legally problematic. As to the departing foreign terrorist fighters, the acts to be criminalized and prosecuted are, as we saw above, all carried out prior to the moment when, and regardless of whether, an individual commits any terrorist act. Travelling to a foreign country, financing such travelling and organizing it are in themselves perfectly lawful activities. Most of us regularly engage in them and that certainly does not turn us into foreign terrorist fighters. What turns individuals foreign terrorist fighters, or into those supporting them, is the specific purpose of the activity. As the Explanatory Report to the Protocol states, 'the real purpose of the travel must be for the perpetrator to commit or participate in terrorist offences, or to receive or provide training for terrorism'. ${ }^{86}$ Foreign terrorist fighters have to act intentionally, and unlawfully, to achieve this purpose. Those financing their travel or organizing or otherwise facilitating it, have to act wilfully, i.e. they need to know that their support goes to an individual who intends to travel for the purpose of terrorism.

Establishing that these elements are present is not always an easy task. First, as the Counter-Terrorism Committee in its 2014 report noted, 'few foreign terrorist fighters reveal their plans before leaving, ${ }^{87}$ Some of them, moreover, may not be fully sure what these plans are. Pushed by the outrage at the events in the target countries and the empathy with victims of these events, by their adherence to the general tenets of the ideology promoted by the group they intend to join, or simply by a search for identity and belonging - the three main motivations which, according to scholars, ${ }^{88}$ are behind the foreign /terrorist/ fighters phenomenon -, these individuals are not likely to have an involvement in terrorism as the main purpose, or even one of the purposes, of their travel. Some probably accept that such involvement will occur, meeting at least the conditions of a dolus eventualis. Others may not even cross this threshold. The same applies to those financing and organizing the travel. Some know very well whom they support and they intend to do so. Others probably either do not know or seek to help for other purposes (family ties, etc.). Distinguishing between the two categories is not always easy.

This may lead to dangerous shortcuts. The purpose may get deduced not from the intentions of a concrete individual but from the nature of the entity this individual decided to join. It is assumed that, if an individual decided to join a terrorist organization, then clearly s/he intended to, in the words of Resolution 2178, 'perpetrate, plan, prepare or participate in terrorist acts or provide or receive terrorist trainings' or, as

86 COD-CTE (015) 3 final, Draft Explanatory Report to the Additional Protocol to the Council of Europe Convention on the Prevention of Terrorism, 26 March 2015, para 48.

87 UNSC, Preliminary analysis of the principal gaps in Member States' capacities to implement Security Council resolutions 1373 (2001) and 1624 (2005) that may hinder their abilities to stem the flow of foreign terrorist fighters pursuant to Security Council resolution 2178 (2014), 12 November 2014, S/2014/807, para 7.

88 Frenett, R, Silverman, T, "Foreign Fighters: Motivations for Travel to Foreign Countries" in De Guttry, A, Capone, F and Paulussen, C, eds, Foreign Fighters under International Law and Beyond (Asser/Springer, 2016), 63. 
a minimum, had to know that this is the highly likely outcome of his/her joining the organization and had to accept this outcome in principle. This assumption has serious flaws. It presupposes that there is a general consensus as to which entities qualify as terrorist organizations and that this consensus is known to, and shared by, individuals joining the entities. Yet, neither of these presumptions is necessarily true. The international community is divided not only with respect to the definition of terrorism but also, and probably even more, with respect to which entities are terrorist and which are not. There is neither a common definition of terrorist groups or organizations, ${ }^{89}$ nor a comprehensive list of all such entities.

Even in the absence of such attempts and despite the general uncertainty linked to the concept, it is possible to say that there is a broad agreement across the international community that certain entities qualify as terrorist organizations. This is the case of entities which have been labelled as terrorist by the UN Security Council, such as ISIS, Al-Qaeda and, possibly, other entities included in the sanction list established under Resolutions $1267 / 1989 / 2253 .^{90}$ It could be argued that even in these cases, individuals joining the ISIS or any other of the entities need not necessarily be aware of the fact that these entities have been designated as terrorist organizations. They may also consider this designation as erroneous and unjust. Finally, they may be aware of the designation but may decide to join the relevant entity despite, rather than because of its involvement in terrorism. Due to the extreme nature of ISIS and ISIS-related entities and the widespread knowledge of this nature, however, such arguments could hold, if at all, only in very atypical and exceptional circumstances. ${ }^{91}$

The situation is more complicated with regard to entities that have not been designated as terrorist organizations by the UN Security Council. There are numerous organizations and groups listed as terrorist in some countries but not in others. ${ }^{92}$ One recent example is that of the Kurdish People's Protection Units (YPG) operating in Syria. The YPG is considered as a terrorist organization in Turkey but not necessarily in EU countries. There have already been cases of individuals who travelled from the EU to join the YPG forces fighting against ISIS, and were prosecuted and sentenced in Turkey as foreign terrorist fighters on account of their activity. ${ }^{93}$ Furthermore, some countries do not even have a list of terrorist organizations and there is thus no a priori indication,

89 Directive 2017/541, supra nt 49, defines a terrorist group as "a structured group of more than two persons, established for a period of time and acting in concert to commit terrorist offences" (Article 2(3)).

90 See UNSC, Threats to international peace and security caused by terrorist acts, 20 November 2015, S/RES/2249 (2015).

91 See NL Times, Pieters, J, Jail Time for Arnhem Terror Suspects, 15 June 2016, at <nltimes.nl/2016/06/15/jail-time-arnhem-terror-suspects> (accessed 23 May 2018). In June 2016, two men from the Netherlands, who had been arrested close to the border between Turkey and Syria, were sentenced to three and two years in prison, respectively, for an attempt to join a terrorist organization, as they had allegedly intended to join ISIS. The men claimed that they had travelled to Syria to help save victims of the civil war, not to engage in terrorism. The court did not find this explanation credible.

92 See the comparative table of the national lists compiled on Wikipedia, List of designated terrorist groups, online at <en.wikipedia.org/wiki/List_of_designated_terrorist_groups\#cite_note-eur-lex.europa.eu-10> (accessed 23 May 2018).

93 See Czech Radio, Willoughby, I, Czech Couple Involved With Kurdish Group Facing Terror Charges in Turkey, 16 November 2016, at <radio.cz/en/section/curraffrs/czech-couple-involved-with-kurdishgroup-facing-terror-charges-in-turkey;> (accessed 23 May 2018); Czech Radio, Velinger, J, Turkish Court Sentences Czechs to More Than Six Years in Prison, 2 August 2017, at $<$ radio.cz/en/section/curraffrs/turkish-court-sentences-czechs-to-more-than-six-years-in-prison> (accessed 23 May 2018). 
whether by joining an entity, individuals undergo a risk of criminal prosecution or not. Deducing the specific intent to engage in terrorism from the nature of this entity - a nature, which is moreover to be established ex post facto in the judicial proceedings - is thus problematic and risks running counter to the principle of legality.

It would seem that this problem does not arise in the prosecution of returnees and relocators. ${ }^{94}$ Here, the international instruments do not request states to introduce new criminal offences, inciting them merely to use the already existing provisions. Depending on the concrete circumstances of the case and the relevant domestic legal order, returnees and relocators may be prosecuted, as far as the activities carried out abroad are concerned, ${ }^{95}$ for murder or causing of serious bodily harm or an attempt thereof, the service in foreign armed forces or the membership in a criminal organization. Yet, when seeking to hold returnees and relocators accountable for these crimes, states may encounter legal and practical difficulties. The offence of serving in foreign armed forces often applies only to those who have joint armed forces of foreign states, as opposed to a non-state actor. Foreign terrorist fighters do not always commit violent crimes and when they do, it might be difficult to secure evidence due to the messy environment in which they operate. Due to these difficulties, states may again opt for an easy option and prosecute returnees and relocators for terrorism or for the membership in, or support of, a terrorist organisation. Then, similar problems as those described above would arise, though for individuals who have actually joined ISIS or a similar entity, it might be even harder to argue that they were unaware of the nature of such an entity. ${ }^{96}$

This subsection is obviously not meant to say that foreign terrorist fighters should not be held accountable for acts they carried out while abroad or they intend to carry out once there. It simply seeks to draw attention to the fact that, as Amnesty International and the International Commission of Jurists noted in their joint commentary on the Additional Protocol, new instruments focus 'on criminalizing ancillary offences arising from conduct which to varying extents is distant from the principal offence ("terrorist

94 See International Centre for Counter-Terrorism, Mehra, T, Bringing (Foreign) Terrorist Fighters to Justice in a Post-ISIS Landscape Part II: Prosecution by Foreign National Courts, 12 January 2018, at $<$ icct.nl/publication/bringing-foreign-terrorist-fighters-to-justice-in-a-post-isis-landscape-part-iprosecution-by-iraqi-and-syrian-courts/>; (accessed 23 May 2018); Bakker, E, Paulussen, C, Entenmann, E, "Returning Jihadist Foreign Fighters. Challenges Pertaining to Threat Assessment and Governance of this Pan-European Problem," 25(1) Security and Human Rights, Vol. 25, (2014) 11.

95 Returnees and relocators may also face charges with regard to activities carried out after their return to the country of origin or their relocation to a third country. Here, the range is potentially even broader, encompassing inter alia - again depending on the concrete circumstances and the legal framework murder or causing of serious bodily harm or an attempt thereof, the membership in a criminal organization, incitement to violence or spreading political or religious hatred. The threat that returnees and relocators may continue to engage in crimes after their return or relocation, is one of the main reasons why this category is paid such attention by the international community. At the same time, the legal framework applicable here is identical for former foreign terrorist fighters and for any other perpetrators.

96 See NL Times, Pieters, J, Dutch Jihadist Sentenced to Six Years in Prison, In His Absence, 4 April 2018, at <nltimes.nl/2018/04/04/dutch-jihadist-sentenced-six-years-prison-absence> (accessed 23 May 2018). In March 2018, a court in Rotterdam, the Netherlands, convicted a Dutch jihadist, Marouane B., to six years in prison on account of terrorism for having joint the ISIS forces in Syria. A year earlier, the man had sent an open letter to Dutch media in which he had claimed that he joined the ISIS forces not for purpose of terrorism but to protect people from the Assad regime. The trial took place in absentia, as Marouane B. has not returned to the Netherlands yet. 
offence") and is therefore more difficult to identify with certainty'. ${ }^{97}$ This, together with the elusive nature of the concept of terrorism and the absence of an international definition thereof, makes the regulation open for diversified use and, potentially, misuse. Due to the uncertainties linked to the interpretation and application of new offences, the principle of legality requiring that laws be clear and accessible, is also at stake. That brings us to the third challenge, which pertains to the impact that the new regulation on foreign terrorist fighters may have, or has already had, on human rights.

\section{Impact on human rights}

Resolution 2178 stresses that 'Member States must ensure that any measures taken to counter terrorism comply with all their obligations under international law, in particular international human rights law [...]'. ${ }^{98}$ It adds that 'respect for human rights, fundamental freedoms and the rule of law are complementary and mutually reinforcing with effective counter-terrorism measures, and are an essential part of a successful counter-terrorism effort'. ${ }^{99}$ The same appeal is repeated, often word for word, in the subsequent resolutions on foreign terrorist fighters, including Resolution 2396. ${ }^{100}$ The Protocol also invokes human rights in several instances, most notably in its Article 8 under which ' $[\mathrm{e}] \mathrm{ach}$ Party shall ensure that the implementation of this Protocol, including the establishment, implementation and application of the criminalisation under Articles 2 to 6, is carried out while respecting human rights obligations'. As an integral part of international law, human rights law would be applicable even in the absence of explicit references to it.

The application of human rights law is one thing, the compliance with this law is another. Over the years, concerns have been raised by scholars ${ }^{101}$ and non-governmental organisations $^{102}$ with respect to this latter issue. Some of these concerns pertain to the definition of foreign terrorist fighters and the construction of the foreign terrorist fightersrelated offences, dealt with in the previous subsections. Here, the principle of legality, as enshrined in Article 15 of the International Covenant on Civil and Political Rights (ICCPS) or Article 7 of the European Convention on Human Rights (ECHR), is particularly at stake, due to the uncertainties surrounding the definition of terrorism and the difficulties implied in establishing the specific purposes of the acts carried out by individuals suspected of being foreign terrorist fighters. To quote once again a joint submission by the Amnesty International and the International Commission of Jurists, 'the absence of any such specific definitions /of terrorism/ raise the concern that [...] states may create broadly-defined criminal offences that fail to satisfy the principle of legality, and that they may apply wide or vague or politicized definitions, including of terrorism, with a risk of abusive, arbitrary or discriminatory application'. ${ }^{103}$

97 Submission of Amnesty International and the International Commission of Jurists to the Council of Europe Committee of Experts on Terrorism (CODEXTER), Draft Additional Protocol to the Council of Europe Convention on the Prevention of Terrorism, 7 April 2015, IOR 60/1393/2015.

98 UNSC, supra nt 17 para 7 of the preamble.

99 UNSC, supra nt 17 para 7 of the preamble.

${ }^{100}$ UNSC, supra nt 36 para 7 of the preamble.

${ }^{101}$ See Tayler, L, supra nt 71; Limbada, Z, Davies, L, "Addressing the Foreign Terrorist Fighter Phenomenon from a Human Rights Perspective" 18(5) International Community Law Review (2016) 483; Ambos, supra nt 66 .

102 See Tayler, L, supra nt 71; Submission of Amnesty International and the International Commission of Jurists, supra nt 97.

${ }^{103}$ Amnesty International, Preliminary public observations on the terms of reference to draft an Additional Protocol supplementing the Council of Europe Convention on the Prevention of Terrorism, 6 March 2015, point 1.1. 
Other concerns, closely linked to the previous ones, pertain to the fair trial guarantees, or the absence thereof, in the trial of foreign terrorist fighters. These guarantees are listed in Article 14 ICCPR and Article 6 ECHR. They include, inter alia, the right to a fair and public hearing, the presumption of innocence and the right to examine, or have examined, witnesses. So far, only a handful of trials involving foreign terrorist fighters or returnees and relocators have taken place, although these trials are geographically spread across numerous countries (Australia, Belgium, Canada, the Czech Republic, Hungary, the Netherlands, Turkey, the United Kingdom, etc.). Most of the trials do not seem to have given rise to suspicions of procedural irregularities. At the same time, such irregularities have been repeatedly found in trials concerning terrorist suspects more generally. Reports show that terrorist suspects have been tried by bodies lacking independence and impartiality, have not been duly informed about charges against them, have been denied access to crucial evidence on account of the state secrecy, could not freely choose their counsel, or have evidence obtained in breach of human rights or domestic law used against them. ${ }^{104}$ Since trials against foreign terrorist fighters are a form of trials with terrorist suspects, the same irregularities are not unlikely to affect them as well.

Other concerns relate to the limitations that states have imposed on various human rights in connection with their attempts to prevent and repress foreign terrorist fighters. Resolution 2178 requests states 'to cooperate in efforts to address the threat posed by foreign terrorist fighters, including by preventing the radicalization $/ . . . /$, preventing foreign terrorist fighters from crossing their borders, disrupting and preventing financial support to foreign terrorist fighters'105 and to 'prevent and suppress the recruiting, organizing, transporting or equipping ${ }^{106}$ of foreign terrorist fighters. Although the resolution simultaneously stresses that states have to act in accordance with their obligations under human rights law, this call has not always been heard and respected. Since a comprehensive overview of limitations imposed on human rights in this context has been provided elsewhere ${ }^{107}$ the following paragraphs provide just examples of such limitations, without any claim to completeness.

First of all, when faced with the threat of terrorism, states frequently resort to emergency legislation. They may also derogate from human rights treaties, with respect to a range of human rights (liberty and security, fair trial, privacy, freedom of expression,

104 See UNGA, Report of the Special Rapporteur on the promotion and protection of human rights and fundamental freedoms while countering terrorism, 6 August 2008; UN Counter Terrorism Implementation Task Force, Basic Human Rights Reference Guide: Right to a Fair Trial and Due Process in the Context of Countering Terrorism, October 2014, CTITF, A/63/223; Ambos, K, Poschadel, A, "Terrorists and Fair Trial: The Right to a Fair Trial for Alleged Terrorists Detained in Guantánamo Bay," 9(4) Utrecht Law Review (2013) 109; Saul, B, "Criminality and Terrorism" in Salinas de Frías, A, Samuel, K, White, ND, eds, Counter-Terrorism: International Law and Practice (Oxford University Press, Oxford, 2012) 133; Hoffman, P, "Human Rights and Terrorism" 26(4) Human Rights Quarterly (2004) 932.; Human Rights Watch, Morocco: Terror Convictions Upheld for 35, Including Political Figures, 28 July 2010, at $<$ hrw.org/en/news/2010/07/28/morocco-terror-convictions-upheld-35-including-political-figures;> (accessed 23 May 2018); International Federation for Human Rights, Syria: Opening of the trial against detained human rights defenders Mazen Darwish, Hussein Ghrer and Hani Al-Zitani for terrorism, 28 March 2014; , at <fidh.org/IMG/article_PDF/article_a15037.pdf> (accessed 22 April 2018); The Guardian, Maldives prosecutor general to appeal against ex-president's conviction, 24 July 2015, at $<$ theguardian.com/world/2015/jul/24/maldives-prosecutor-general-appeal-against-mohamed-nasheedconviction> (accessed 23 May 2018).

${ }^{105}$ UNSC, supra nt 17 para 4.

106 UNSC, supra nt 17 para 5.

107 Tayler, supra nt 71. 
freedom of movement etc.). Since 2014, at least eight countries have enacted emergency laws invoking, in one way or another, the threat of terrorism. These are Egypt, Ethiopia, France, Malaysia, Mali, Tunisia, Turkey and Ukraine. France, Turkey and Ukraine have also formally derogated from the ICCPR and the ECHR. Although none of the emergency regimes has been triggered specifically by foreign terrorist fighters, these fighters, due to their link to terrorism, would be subject to them. For instance, Turkey declared a state of emergency and derogated from the ICCPR and the ECHR after an unsuccessful coup d'etat which took place on 15 July 2016. ${ }^{108}$ The derogation is extensive and concerns a wide range of human rights (freedom and security, privacy, freedom of expression, freedom of assembly, a fair trial, the right to vote and take part in public affairs, etc.). The exceptional measures are still in force at the time when the first trials with foreign terrorist fighters take place in Turkey and they lower the procedural standard for these trials as well as the general standard of the protection of human rights in the country.

States have imposed limitations on human rights in connection with foreign terrorist fighters both during the state of emergency and outside it. The limitative measures include, among others, travel bans, the revocation of citizenship, preventive detention and intrusions into privacy. ${ }^{109}$ Travel bans have been recently enacted in Austria, Australia, Azerbaijan, Belgium, Denmark, Egypt, France, Israel, Italy, Malaysia, the Netherlands, New Zealand, Tajikistan, Tunisia, and the UK. Although the concrete form differs, the measure typically entails suspension of passports and IDs for individuals suspected of intending to become foreign terrorist fighters. The right to freedom of movement and to leave one country, including one's own, enshrined in Article 12 ICCPR and Article 2 of Protocol 4 to the ECHR, is at stake here. It is not an absolute right and can be limited but only within the confines prescribed by law and to the extent necessary to achieve a legitimate purpose (e.g. national security or the prevention of crime). Travel bans may be justified but they have to meet these conditions and not to interfere with other protected rights. Yet, this seems to be the case in some countries. For instance, Egypt and Tunisia have issued general bans to travel to the Middle East applicable to men under 35 or 40. Australia criminalizes travel to a 'declared area where terrorist organizations engage in hostile activity ${ }^{110}$ and it is up to the individual to prove that they had a legitimate reason to travel to such an area, thus shifting the burden of prove.

The right to citizenship is guaranteed in Article 15 of the Universal Declaration of Human Rights. Depriving individuals of citizenship if such a measure would result in statelessness could also run contrary to the 1954 Convention on the Reduction of Statelessness and, arguably, customary international law. Over the past years, it has become common to include the revocation of citizenship among the sanctions foreseen for individuals engaged in terrorism, including foreign terrorist fighters. Austria, Australia, Bahrain, Belgium, Canada, and the UK are some of the countries using this tool. ${ }^{111}$ In most of these countries, the sanction can only be applied to individuals with dual citizenship. This is not in itself a violation of international standards, as long as the sanction is imposed in a regular judicial process and does not result in a de facto statelessness. In

108 CoE, Declaration contained in a letter from the Permanent Representative of Turkey, 21 July 2016; UN Secretariat, Notification under Article 4(3), 2 August 2016, C.N.580.2016.Treaties-IV.4.

109 Tayler, supra nt 71.

110 Section 119.2 of the Criminal Code of Australia.

111 See Amnesty International, Arbitrary Deprivation of Citizenship, Seminar Held on 31 October 2016, Amnesty International, 2017. 
some countries, however, the dual citizenship condition is not present. There are also allegations that the measure is used as a means to remove dissidents and human rights activists from the country. ${ }^{112}$

Preventive detention is another measure, which has become increasingly popular in the fight against terrorism. ${ }^{113}$ The notion refers to the detention, which occurs before or even without charge to control a person who is, typically, considered to constitute a threat to the society. The right to freedom and security, enshrined in Article 9 ICCPR and Article $5 \mathrm{ECHR}$, allows for preventive detention but only under strict conditions. As the UN Human Rights Committee held in 1982, '[i]f so-called preventive detention is used, for reasons of public security, [...] it must not be arbitrary, and must be based on grounds and procedures established by law [...], information of the reasons must be given [...] and court control of the detention must be available [...] as well as compensation in the case of a breach [...]'. ${ }^{114}$ Prevention detention has been used in Australia, Canada, France or the UK, with respect to departing foreign terrorist fighters - to prevent them from leaving, as well as to returnees and relocators - to prevent them from engaging in violent acts upon their return or relocation. There is a risk that the detention will be based on the group rather than the individual threat assessment and will entail departures from the conditions set by the Committee (grounds not communicated due to the protection of state secrecy, judicial control unavailable or delayed, etc.).

The right to privacy, enshrined in Article 17 ICCPR and Article 6 ECHR, has suffered considerable restrictions over the past years. Some of these restrictions are even explicitly foreseen by international instruments on foreign terrorist fighters. For example, Resolution 2178 calls upon states to require airlines operating in their territory to provide advance passenger information (API), i.e. data collected from government-issued passport or other official documents. ${ }^{115}$ Such a measure of itself may be fully compatible with the right to privacy and the protection of personal data, which, again, are not absolute rights. Yet, concerns have been expressed as to the potential retention of the personal data, their use for other purposes than national security and their disclosure to third parties. ${ }^{116}$ The right to privacy is also at stake in connection with the extended powers of the police and intelligence services allowing them to monitor private communications, and with some of the measures indicated above such as preventive detention. Thus, although Resolution 2178 stresses the importance of human rights, it introduces a regime which may lead to, and justify, disrespect of these rights.

\section{Concluding Remarks}

Resolution 2178 repeatedly invokes the threat posed by foreign terrorist fighters noting that these fighters 'increase the intensity, duration and intractability of conflicts, and also may pose a serious threat to their States of origin, the States they transit and the States to which they travel [...]'. ${ }^{117}$ This phenomenon is nowadays mostly connected with the

\footnotetext{
112 The Washington Post, Bahrain is stripping dissidents of their citizenship, and the U.S. is silent, 8 July 2017, at $<$ washingtonpost.com/world/middle_east/bahrain-is-stripping-dissidents-of-their-citizenship-and-theus-is-silent/2017/07/08/3ad347d0-5154-11e7-91eb-9611861a988f_story.html?noredirect=on\&utm_ term $=.0 \mathrm{~d} 508 \mathrm{bc52 \textrm {fa } 3}>$ (accessed 23 May 2018).

113 See Webber, supra nt 66.

114 UN HRC, CCPR General Comment No. 8: Article 9 (Right to Liberty and Security of Persons), 30 June 1982, para 4.

115 UNSC, supra nt 17 para 9.

116 UNSC, Gaps in the use of advance passenger information and recommendations for expanding its use to stem the flow of foreign terrorist fighters, 26 May 2015, S/2015/377, para 44

117 UNSC, supra nt 17 para 10 of the preamble.
} 
conflict with ISIS, yet it is certainly not limited to this, or any other particular region. That is the reason why the UN Security Council, while responding primarily to the events in the Middle East, has decided to deal with foreign fighting in a general way, without any temporal and territorial limits. Although this approach might be problematic, with the Security Council assuming the role of legislator that the UN Charter does not confer on it, the international community has, at least in the area of counter-terrorism, so far refrained from contesting it in any serious manner. States have started to implement the obligations stemming from Resolution 2178 and other resolutions either directly, or through regional instruments. There are still gaps in the implementation. ${ }^{118}$ These gaps, however, seem to have more to do with the factual capacity of states to abide by new obligations than with their readiness to accept these obligations.

This is not all that surprising and all that positive as one might think. Due to the reference to the still undefined concept of terrorism, the definition of foreign terrorist fighters remains imprecise and open to the creative (re)interpretation at the national level. The foreign terrorist fighters-related offences that Resolution 2178 requests states to criminalise and prosecute are construed in such a way as to leave, again, large discretion to national organs to decide whom they wish to qualify and prosecute as foreign terrorist fighters. Even states seeking to implement and apply the new regulation in good faith may in this situation get over the line and depart from the principle that any counterterrorist measures have to comply with international law, including human rights law. The regime built around the concept of foreign terrorist fighters thus risks becoming of itself a threat to the values that it is supposed to protect. And since respect for human rights is an integral part of any successful counter-terrorist strategy, it also risks jeopardising its own purposes. The international community, with the UN Security Council in the lead, would thus do well to reconsider the contours and the content of the new regime and to ponder whether the 'terror-isation' of international law that we have witnessed over the past years is a solution to the problem of terrorism or rather, and increasingly, a part of this problem.

$*$

www.grojil.org

${ }^{118}$ UNSC, supra nt 87 para 7. 